\title{
Proliferation of the $\beta$-Cells of Pancreas in Diabetic Rats Treated with Urtica Dioica
}

\author{
Proliferación de las Células $\beta$ del Páncreas en Ratas Diabéticas Tratadas con Urtica Dioica
}

"Mohammad Jafar Golalipour; **Soraya Ghafari; ${ }^{* * * *}$ Vahid Kouri \& ${ }^{* * * *}$ Abbas Ali Kestkar

GOLALIPOUR, M. J.; GHAFARI, S.; KOURI, V. \& KESTKAR, A. A. Proliferation of the b-cells of pancreas in diabetic Rats treated with Urtica dioica. Int. J. Morphol., 28(2):399-404, 2010.

SUMMARY: This investigation was carried out to evaluate the effect of the extract of Urtica dioica leaves on hyperglycemia and quantitative changes of $\beta$-cells in streptozotocin-diabetic rats. Forty male Wistar rats were allocated in groups of normal, diabetic, treatment and protective. Hyperglycemia induced by administrating one dose of $80 \mathrm{mg} / \mathrm{kg}$ streptozotocin (STZ) intraperitoneally. Animals in treatment group received Urtica dioica $(100 \mathrm{mg} / \mathrm{kg} /$ day $)$ for 4 weeks intraperitoneally, one week after injection of STZ. In protective group animals received $U$. dioica $(100 \mathrm{mg} / \mathrm{kg} /$ day) for 5 days before inducing diabetes. After five weeks the animals were sacrificed and whole pancreas removed. Pancreas specimens were used for quantitative morphometric analysis after Chromealum hematoxiline - phloxine staining. The mean $\pm \mathrm{SE}$ of $\beta$-cells in non hyperglycemic animals in protective group was higher than in hyperglycemic animals in the same group $(54.33 \pm 2.4$ versus $1.25 \pm 0.5, \mathrm{P}<0.05)$. Hyperglycemia was improved in $6(60 \%)$ of rats in protective group and $1(10 \%)$ rat in treatment group $\mathrm{OR}=0.07$ (CI 95\%: 0.0-1.1, $\mathrm{p}=0.06$ ). The logistic regression analysis showed an association between decrease of blood glucose, increase of number of b-cells and administration of Urtica before induction of diabetes. This study showed proliferation of b-cells when of the $U$. dioica leaves extract $(100 \mathrm{mg} / \mathrm{kg} / \mathrm{day})$ administrated before induction of diabetes in animal model.

KEY WORDS: Streptozotocin; Diabetes; Urtica dioica; Rat; Pancreas; $\beta$-cells; Blood glucose.

\section{INTRODUCTION}

Diabetes is a complex and multifarious group of disorders characterized by hyperglycemia reached epidemic proportions in the present century (Chen et al., 2005).

Plants used in folk medicine to treat diabetes mellitus represent a viable alternative for the control of this disease (Maroo et al., 2002).

Urtica dioica ( $U$. dioica), an annual and perennial herb of family Urticaceae is commonly known as medical herb for a long time in the world. This herb is known for its anti- inflammationtory activity (Obertries et al., 1996; Riehemann et al., 1999). There have been also other reports indicating the benefits of using the extract of the leaves or other parts for the use in different conditions, i.e., diabetes (Kavalali et al., 2003; Román Ramos et al., 1992; Petleveski et al., 2003; Farzami et al., 2003) as well as other disorders like prostatic hyperplasia (Hirano et al., 1994; Lichius \& Muth, 1997; Kayser et al., 1995), rheumatoid arthritis, hypertension and allergic rhinitis (Mittman, 1990), stimulation of human lymphocytes (Wagner et al., 1989) and decreasing the lipid peroxidation and liver enzymes (Kanter et al., 2003).

Although, there are some reports regarding the hypoglycemic activity of $U$. dioica in folk medicine (Petleveski et al.; Farzami et al.) but, in other hand, several investigations have detected hyperglycemic activity of this herb (Neef et al., 1995; Swanston-Flatt et al., 1989).

Therefore, this study was done to evaluate the effects of the hydroalcoholic extract of $U$. dioica leaves on hyperglycemia and Proliferation of $\beta$-cells in streptozotocindiabetic rats.

\footnotetext{
* Professor, Department of Embryology and Histology, Golestan University of Medical Sciences, Gorgan, Iran.

** Department of Embryology and Histology, Golestan University of Medical Sciences, Gorgan, Iran.

*** Associate Professor, Department of Pharmacology and Toxicology, Golestan University of Medical Sciences, Gorgan, Iran.

**** Assistant Professor, Department of Health, Golestan University of Medical Sciences, Gorgan, Iran.
} 


\section{MATERIAL AND METHOD}

Plant material. $U$. dioica leaves were collected from cultivated plant, from suburb of Gorgan, northern Iran (Golestan, Iran) in 2007 and taxonomically identified by Department of Pharmacognosy, Mazandaran University of Medical Sciences. A voucher specimen (5-77-1) was deposited in the herbarium of Mazandaran University.

Preparation of the hydroalcoholic extract of Urtica dioica. Powder of $U$. dioica leaves was percolated by hydroalcoholic $\left(60^{\circ}\right)$ solvent for 48 hours. The extract was filtered and concentrated under vacuum at $40^{\circ} \mathrm{C}$ to make a jellied material by vacuum spray dryer. In addition to thin layer chromatography and purity tests (foreign matter, total ash, acid insoluble ash and water insoluble ash) for qualificative analysis, monosaccharide-linked spectrophotometric assay were carried out to determine the concentration of polysaccharides in $U$. dioica leaves for standardization of the extract. The results of phytochemical analysis showed presence of high percentage of tannins, steroids and low percentage of flavonoids, carotenoids and saponins in the leaves of $U$. dioica.

Animals. Male adult albino rats (Wistar strain) of 125-175 gr were fed on pellet diet and tap water for full acclimatization. The animals were kept in air-conditional animal room $\left(22 \pm 2^{\circ} \mathrm{C}\right)$ under a $12 \mathrm{~h}$ light/dark cycle. The rats were divided into four groups (each group including 10 rats).

Experimental design. Hyperglycemia (blood glucose range of above $200 \mathrm{mg} / \mathrm{dl}$ (Rasal et al., 2006) was induced with single IP injection of streptozotocin (STZ) at a dose of 80 $\mathrm{mg} / \mathrm{kg}$ body weight dissolved in distilled water just before use to overnight fast rats.

Blood samples for glucose measurements were taken from the tail vein. Diabetes was confirmed by measuring the glucose concentration by using Accu-check active blood glucose monitor test strip (Jackson-Guilford et al., 2000).

In the experiments, ten rats were used in each group.

Group I: normal control group. Saline daily for 5 weeks. Group II: diabetic group. Saline daily administered for 5 days and then, hyperglycemia induced by one dose of intraperitoneally injection of $80 \mathrm{mg} \mathrm{STZ}$ at day $6^{\text {th }}$.

Group III: treatment Group (STZ-Urtica): hyperglycemia induced by one dose of intraperitoneally injection of $80 \mathrm{mg}$ STZ and then diabetic rats received $100 \mathrm{mg} / \mathrm{kg}$ daily hydroalcoholic extract (Kavalali et al.) of $U$. dioica, for 4 weeks.
Group IV: protective group (Urtica-STZ): animals received $100 \mathrm{mg} / \mathrm{kg}$ daily hydroalcholic extract of $U$. dioica, for 5 days, intraperitoneally and then, hyperglycemia induced by one dose of intraperitoneally injection of $80 \mathrm{mg} \mathrm{STZ}$ at day $6^{\text {th }}$.

Glucose tolerance test. Intraperitoneal glucose tolerance test (GTT) was performed on $16 \mathrm{hrs}$ fasted rats using 2 gram glucose/kg body weight. In all groups, blood was collected from the animals by tail snipping at $0,30,90$ and 120 minutes after glucose load. Also glucose test were performed after IP injection STZ in 1, 3 and 5 weeks.

Histopathologic examinations. The animals of three groups are sacrificed by ether anesthesia. Whole pancreas was dissected. The tissue samples were fixed in bouin's fluid and paraffin embedded for microscopic examination in accordance with routine laboratory procedures. Histopathologic examination and grading were carried out on Chromealum hematoxiline - phloxine (Bancroft \& Gamble, 1990) stained sections at 5- $\mu \mathrm{m}$ thickness with 30$\mu \mathrm{m}$ distance were used for and morphometric analyses.

The number of islets and the number of b-cells of each islet were counted by Olympus BX-51T-32E01 research microscope connected to DP 12 Camera with 3.34 million pixel resolution and Olysia Bio software (from: Olympus Optical Co. LTD, Tokyo-Japan).

Statistical analysis. All the grouped data were statistically evaluated using One-Way ANOVA, expressed as the Mean \pm SE from ten rats in each groups. Furthermore, Odds ratios and $95 \%$ confidence interval (CI) were calculated using SPSS 11.5. In all of the statistical tests, significance level was set 0.05 .

\section{RESULTS}

The animals in the end of fifth week according to glucose level (blood glucose range of above $200 \mathrm{mg} / \mathrm{dl}$ ) and GTT test (Fig. 1) grouped to two groups.

As shown in Table I the mean \pm SE of blood glucose concentrations at the beginning of the study were $85.5 \pm 1.7$, $102.9 \pm 3.7,92.2 \pm 4.1$ and $95.6 \pm 3.7 \mathrm{mg} / \mathrm{dl}$ in control, diabetic, treatment and protective groups, respectively.

In the end of fifth week the mean \pm SE of the glucose level in control and STZ groups were $99.4 \pm 5$ and $454.7 \pm$ 34.5 respectively. Hyperglycemia was seen in 9 (90\%) animals in STZ-Urtica and 4 (40\%) animals in protective 


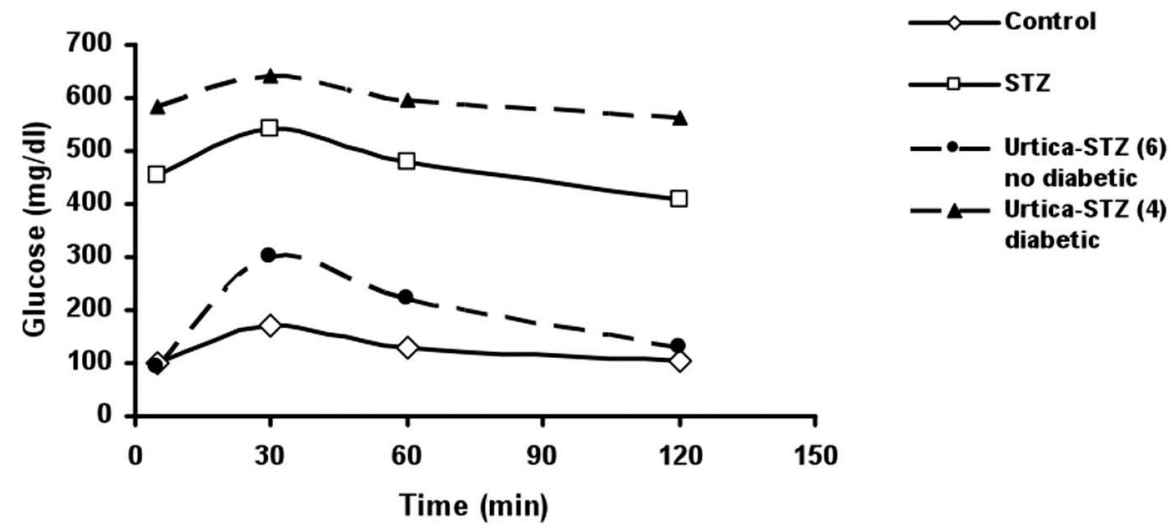

Fig. 1. The curves of Glucose Tolerance Test (GTT) in Control, STZ and protective groups (Day 35).

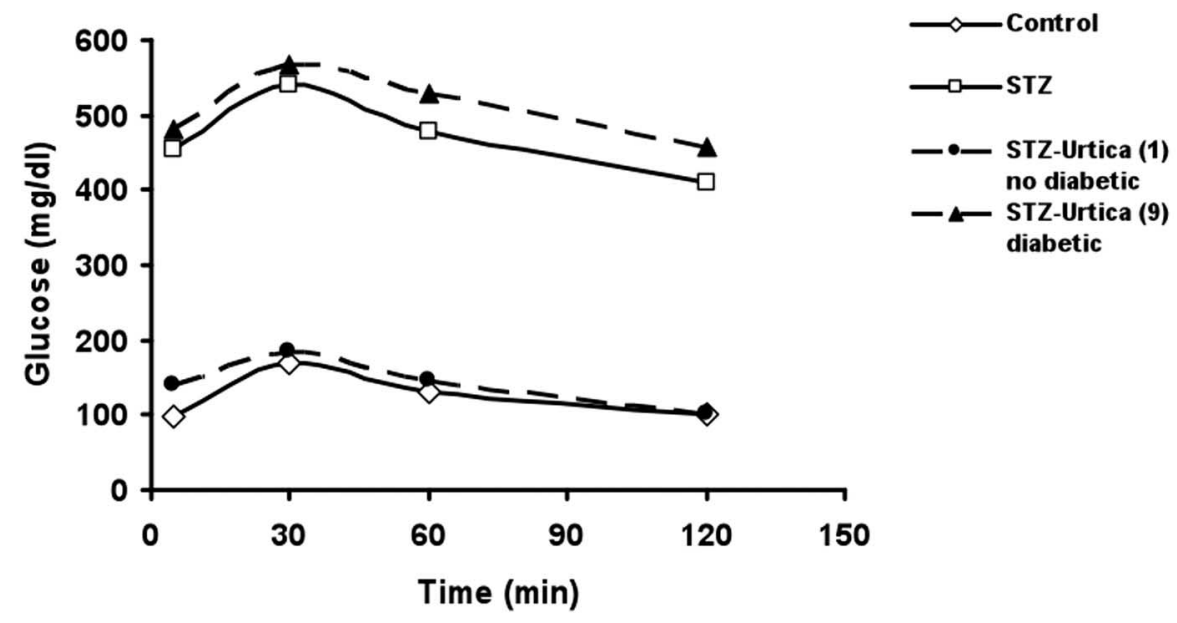

Fig. 2. The curves of Glucose Tolerance Test (GTT) in Control, STZ and treatment groups (Day 35).

Table I. Blood glucose concentration and number of b cells in Control, Diabetic, Treatment and Protective Groups. Results are expressed as Mean \pm SE of the mean (p-value $<0.05$ ). *In the end of fifth week 1 and 6 non diabetic rats in treatment and protective groups respectively.

\begin{tabular}{|c|c|c|c|c|c|}
\hline & \multirow{2}{*}{ Groups } & \multirow{2}{*}{$\begin{array}{c}\text { Initial } \\
\text { Glucose }\end{array}$} & \multicolumn{3}{|c|}{ In the end of fifth week } \\
\hline & & & & Glucose & B cells \\
\hline \multirow{2}{*}{$\mathbf{I}$} & \multirow{2}{*}{ Control } & \multirow{2}{*}{$85.5 \pm 1.7$} & Normal (10) & $99.4 \pm 5.0$ & $206.5 \pm 17.1$ \\
\hline & & & Diabetic (0) & - & - \\
\hline \multirow{2}{*}{ II } & \multirow{2}{*}{ Diabetic } & \multirow{2}{*}{$102.9 \pm 3.7$} & Normal (0) & - & - \\
\hline & & & Diabetic (10) & $454.7 \pm 34.5$ & $2.4 \pm 0.7$ \\
\hline \multirow{2}{*}{ III } & \multirow{2}{*}{ Treatment } & \multirow{2}{*}{$92.2 \pm 4.1$} & Nondiabetic (1)* & $140 \pm 0.0$ & $10.0 \pm 0.0$ \\
\hline & & & Diabetic (9) & $481.55 \pm 28.28$ & $1.8 \pm 0.3$ \\
\hline \multirow{2}{*}{ IV } & \multirow{2}{*}{ Protective } & \multirow{2}{*}{$95.6 \pm 3.7$} & Nondiabetic (6)* & $93.67 \pm 14.09$ & $54.33 \pm 2.4$ \\
\hline & & & Diabetic (4) & $583.75 \pm 10.31$ & $1.25 \pm 0.5$ \\
\hline
\end{tabular}


groups, respectively $\mathrm{OR}=0.074$ (CI 95\%: $0.007-0.835, \mathrm{P}$ value $=0.035$ ).

In the fifth week of the study Mean \pm SE of $\beta$-cells in control and diabetic group was $206 \pm 17$ and $2.4 \pm 0.7$ respectively, also, mean \pm SE of beta cells in STZ-Urtica and Urtica-STZ groups were shown in Table I. The mean \pm $\mathrm{SE}$ of b-cells in non hyperglycemic animals in protective group (Urtica-STZ) was higher than in hyperglycemic animals in the same group $(54.33 \pm 2.4$ versus $1.25 \pm 0.5$, $\mathrm{p}<0.05)$.

According to our results administration of Urtica dioica before induction of diabetes, 13.5 times decrease chance of diabetes (Table II) and increasing number of bcells in streptozotocin diabetic rats (Table III).

Table II. Number and percent of diabetic and non diabetic animals in treatment and protective groups.

\begin{tabular}{cccccc}
\hline Groups & Diabetic $(\%)$ & No diabetic & P-value & OR & CI \\
\hline Treatment & $9(90 \%)$ & $1(10 \%)$ & 0.035 & 0.074 & $0.007-0.835$ \\
Protective & $4(40 \%)$ & $6(60 \%)$ & & & \\
\hline
\end{tabular}

Table III. A comparison of number of $\beta$-cells in treatment and protective groups.

\begin{tabular}{cccccc}
\hline Groups & Less than 10 & More than 10 & P-value & OR & CI \\
\hline Treatment & $9(90 \%)$ & $1(10 \%)$ & 0.035 & 13.50 & $1.19-152.21$ \\
Protective & $4(40 \%)$ & $6(60 \%)$ & & & \\
\hline
\end{tabular}

\section{DISCUSSION}

This study showed that the administration of the $U$. dioica leaves before induction of diabetes in animals can increasing proliferation of $\beta$-cells and deceasing of blood glucose concentration in $60 \%$ of Rats.

The findings of this study are similar to other studies (Bnouham et al., 2003; Petleveski et al.; Farzami et al.; Kavalali et al.).

Acute and chronic hypoglycemic activity of Urtica was demonstrated by Farzami et al. and Kavalali et al. Farzami et al. showed that a fraction from $U$. dioica was a potent stimulator of insulin release of $\beta$-cells. Also Kavalali et al. reported that lectin fraction of extract of $U$. pilulifera seed has hypoglycemic activity and b-cell regenerative potency.

In the other hand our findings in contrast with two previous studies (Neef et al.; Román Ramos et al.). These studies have not shown the hypoglycemia activity of aqueous extract of $U$. dioica. In contrast with our study, two studies (Neef et al.; Román Ramos et al.) have not shown the hypoglycemia activity of aqueous extract of $U$. dioica.

In this study, in treatment group (STZ-Urtica) the leaves extract of $U$. dioica can cause hypoglycemia activity and ability to regenerate pancreatic $\beta$-cells after four weeks of administrating of $U$. dioica in $10 \%$ of streptozotocin- diabetic rats. It may be the animals probably the $\beta$ cells damage is so extensive that no increase in insulin Secretion is possible. However in protective group (Urtica-STZ), we showed proliferation of $\beta$-cells diabetic rats in 60 percent of animals.

Therefore, it could be suggested that the contact of the leaves extract might play a protective role in preventing free-radials actions, that may destroy $\beta$-cells, those would then cause more secretary ability of $\beta$-cells this decrease plasma glucose concentration.

$U$. dioica probably increased proliferation of $\beta$-cells of islets in the pancreas. Our results indicated that decreased blood glucose concentration by $U$. dioica before induction of diabetes might be due to proliferation roles or partial regeneration in the $\beta$-cells. However, other extra pancreatic mechanisms such as enhanced glucose transport into the cells, inhibition of the endogenous glucose production can not role out by the results of present study.

Also, some studies reported that inhibition of free radical scavenger enzymes and enhancing production of the superoxide radical are the mechanism of STZ on pancreatic $\beta$-cells (Swanston-Flatt et al.). Ford et al. (1999) showed the role of free radicals in disruption of insulin action and impairing glucose tolerance test. Although STZ produce hyperglycemia in a concentration depended model by selective $\beta$-cell cytotoxic effect (Saini et al., 1996). 
Our findings suggest that $U$. dioica may have antioxidant or free radical scavenger properties. Antioxidant and free radical scavenging properties of $U$. dioica leaves have been established by several studies (Kanter et al., 2005; Cetinus et al., 2005; Mavi et al., 2004).

In conclusion, this study showed that the administration of the $U$. dioica leaves before induction of hyperglycemia in rats can increase proliferation of b-cells in animals and decrease the blood glucose concentration.
Further studies are required for understanding of exact mechanism of $U$. dioica leaves on proliferation of $\beta$-cells.

\section{ACKNOWLEDGMENT}

We thanks from research Department of Gorgan University of medical sciences for financial support and Mr. Qurbani.

GOLALIPOUR, M. J.; GHAFARI, S.; KOURI, V. \& KESTKAR, A. A. Proliferación de las células $\beta$ del páncreas en ratas diabéticas tratadas con Urtica dioica. Int. J. Morphol., 28(2):399-404, 2010.

RESUMEN: Este estudio evalúa el efecto del extracto de hojas de Urtica dioica sobre la hiperglicemia y de los cambios cuantitativos de células $\beta$ en ratas diabéticas por estreptozotocina. Cuarenta ratas Wistar macho, fueron distribuidas en grupos normal, diabético, en tratamiento y protector. La hiperglicemia fue inducida, por vía intraperitoneal, a través de la administración de una dosis de $80 \mathrm{mg} / \mathrm{kg}$ de estreptozotocina (STZ) . Los animales del grupo en tratamiento recibieron Urtica dioica (100 mg/kg/día) durante $4 \mathrm{semanas}$ por vía intraperitoneal, una semana después de la inyección de STZ. En los animales del grupo de protección recibieron $U$. dioica (100 $\mathrm{mg} / \mathrm{kg} /$ día) durante 5 días antes de inducir la diabetes. Después de cinco semanas, los animales fueron sacrificados y se extirpó el páncreas. Muestras de páncreas se utilizaron para el análisis morfométrico cuantitativo después de la tinción hematoxilina/floxina. La media \pm SE de células $\beta$ en los animales sin hiperglicemia y en el grupo de protección fue mayor que en los animales con hiperglicemia $(54,33 \pm 2,4$ frente a $1,25 \pm 0,5, \mathrm{p}<0,05)$. La hiperglicemia mejoró en $6(60 \%)$ de las ratas del grupo de protección y 1 (10\%) de ratas en grupo de tratamiento $\mathrm{OR}=0,07$ (IC 95\%: 0,0-1,1, p=0,06). El análisis de regresión logística mostró una asociación entre la disminución de la glucosa en sangre, aumento del número de células $\beta$ y la administración de Urtica antes de la inducción de la diabetes. Este estudio mostró una proliferación de las células $\beta$ cuando el extracto de las hojas de $U$. dioica $(100 \mathrm{mg} / \mathrm{kg} / \mathrm{día})$ administrado antes de la inducción de la diabetes en modelos animales.

PALABRAS CLAVE: Estreptozotocina; Diabetes; Urtica dioica; Rata; Páncreas; Células b; Glucosa en sangre.

\section{REFERENCES}

Bancroft, J. D. \& Gamble, M. Theory and practice of histological techniques. $3^{\text {rd }}$ Ed. London, Churchill Livingstone, 1990. pp.109-12.

Bnouham, M.; Merhfour, F. Z.; Ziyyat, A.; Mekhfi, H.; Aziz, M. \& Legssyer, A. Antihyperglycemic activity of the aqueous extract of Urtica dioica. Fitoterapia, 74(7-8):677-81, 2003.

Cetinus, E.; Kilinc, M.; Inanc, F.; Kurutas, E. B. \& Buzkan, $\mathrm{N}$. The role of Urtica dioica (urticaceae) in the prevention of oxidative stress caused by tourniquet application in rats. Tohoku J. Exp. Med., 205(3):21521, 2005.

Chen, H.; Brahmbhatt, S.; Gupta, A. \& Sharma, A. C. Duration of streptozotocin-induced diabetes differentially affects p38-mitogen-activated protein kinase (MAPK) phosphorylation in renal and vascular dysfunction. Cardiovasc. Diabetol., 4(1):3, 2005.
Farzami, B.; Ahmadvand, D.; Vardasbi, S.; Majin, F. J. \& Khaghani, Sh. Induction of insulin secretion by a component of Urtica dioica leave extract in perfused islets of Langerhans and its in vivo effects in normal and streptozotocin diabetic rats. J. Ethnopharmacol., 89:47-53, 2003.

Ford, E. S.; Will, J. C.; Bowman, B. A. \& Narayan, K. M. Diabetes mellitus and serum carotenoids: findings from the Third National Health and Nutrition Examination Survey. Am. J. Epidemiol., 149(2):168-76, 1999.

Hirano, T.; Homma, M. \& Oka, K. Effects of stinging nettle root extracts and their steroidal components on the $\mathrm{Na}+, \mathrm{K}(+)$-ATPase of the benign prostatic hyperplasia. Planta Med, 60(1):30-3,1994.

Jackson-Guilford, J.; Leander, J. D. \& Nisenbaum, L. K. The effect of streptozotocin-induced diabetes on cell proliferation in the rat dentate gyrus. Neurosci. Lett., 293(2):91-4, 2000. 
Kanter, M.; Coskun, O. \& Budancamanak, M. Hepatoprotective effects of Nigella sativa L and Urtica dioica L on lipid peroxidation, antioxidant enzyme systems and liver enzymes in carbon tetrachloride-treated rats. World J. Gastroenterol., 11(42):6684-8, 2005.

Kanter, M.; Meral, I.; Dede, S.; Gunduz, H.; Cemek, M.; Ozbek, H. \& Uygan, I. Effects of Nigella sativa L. and Urtica dioica L. on lipid peroxidation, antioxidant enzyme systems and some liver enzymes in CCl4-treated rats. $J$. Vet. Med. A. Physiol. Pathol. Clin. Med., 50(5):264-8, 2003.

Kavalali, G.; Tuncel, H.; Göksel, S. \& Hatemi, H. H. Hypoglycemic activity of Urtica pilulifera in streptozotocin-diabetic rats. J. Ethnopharmacol., 84(23):241-5, 2003.

Kayser, K.; Bubenzer, J.; Kayser, G.; Eichhorn, S.; Zemlyanukhina, T. V.; Bovin, N. V.; Andre, S.; Koopmann, J. \& Gabius, H. J. Expression of lectin, interleukin-2 and histopathologic blood group binding sites in prostate cancer and its correlation with integrated optical density and syntactic structure analysis. Anal. Quant. Cytol. Histol., 17(2):135-42, 1995.

Lichius, J. J. \& Muth, C. The inhibiting effects of Urtica dioica root extracts on experimentally induced prostatic hyperplasia in the mouse. Planta Med., 63(4):307-10, 1997.

Maroo, J.; Vasu, V. T.; Aalinkeel, R. \& Gupta, S. Glucose lowering effect of aqueous of Enicostemma littorale Blume in diabetes: a possible mechanism of action. $J$. Ethnopharmacol., 81(3):317-20, 2002.

Mavi, A.; Terzi, Z.; Ozgen, U.; Yildirim, A. \& Cos sun, M. Antioxidant properties of some medicinal plants: Prangos ferulacea (Apiaceae), Sedum sempervivoides (Crassulaceae), Malva neglecta (Malvaceae), Cruciata taurica (Rubiaceae), Rosa pimpinellifolia (Rosaceae), Galium verum subsp. verum (Rubiaceae), Urtica dioica (Urticaceae). Biol. Pharm. Bull., 27(5):702-5, 2004.

Mittman, P. Randomized, double-blind study of freeze-dried Urtica dioica in the treatment of allergic rhinitis. Planta Med., 56(1):44-7, 1990.

Neef, H.; Declereq, P. \& Laekeman, G. Hypoglycemic activity of selected European plants. Phytother. Res., 9:45-8, 1995.

Obertreis, B.; Giller, K.; Teucher, T.; Behnke, B. \& Schmitz, H. Anti-inflammatory effect of Urtica dioica folia extract in comparison to caffeic malic acid. Arzneimittelforschung, 46(1):52-6, 1996.

Petlevski, R.; Hadzija, M.; Slijepcevic', M.; Juretic', D. \& Petrik, J. Glutathione S-transferases and malondialdehyde in the liver of NOD mice on short-term treatment with plant mixture extract P-9801091. Phytother. Res., 17(4):311-4, 2003.

Rasal, V. P.; Shetty, B. B.; Sinnathambi, A.; Yeshmaina, S. \& Ashok, P. Antihyperglycaemic and antioxidant activity of Brassica Oleracea in streptozotocin diabetic rats. Internet J. Pharmacol., 4:2, 2006.

Riehemann, K.; Behnke, B. \& Schulze-Osthoff, K. Plant extracts from stinging nettle (Urtica dioica), an antirheumatic remedy, inhibit the proinflammatory transcription factor NF-kappaB. FEBS Lett., 442(1):8994, 1999.

Román Ramos, R.; Alarcón-Aguilar, F.; Lara-Lemus, A. \& Flores-Saenz, J. L. Hypoglycemic effect of plants used in Mexico as antidiabetics. Arch. Med. Res., 23(1):5964, 1992.

Saini, K. S.; Thompson, C.; Windterford, C. M.; Wlaker, N. I. \& Cameron, D. P. Sterptozotocin at low doses induce apoptosis and at high doses cause necrosis in murine pancreatic beta cell line INS-1. Biochem. Mol. Biol. Int., 39:1229-36, 1996.

Swanston-Flatt, S. K.; Day, C.; Flatt, P. R.; Gould, B. J. \& Bailey, C. J. Glycaemic effects of traditional European plant treatments for diabetes. Studies in normal and streptozotocin diabetic mice. Diabetes Res., 10(2):69-73, 1989.

Wagner, H.; Willer, F. \& Kreher, B. Biologically active compounds from the aqueous extract of Urtica dioica. Planta Med., 55(5):452-4, 1989.

\section{Correspondence to:}

Dr. Mohammad Jafar Golalipour

Department of Histology and Embryology

Golestan University of Medical Sciences, Gorgan

P.O. Box: 49175-553

IRAN

Tel/Fax: +98 (171) 4425165, 4425660

Email: mjgolalipour@yahoo.com

Received: 01-10-2009

Accepted: 25-11-2009 